\title{
Surface layers of Eubacterium yurii subsp. yurii and their possible role in test-tube brush formation and iron acquisition
}

\author{
G. N. KRYWOLAP, W. FISCHLSCHWEIGER*, CAROLYN L. DABIRSIAGHI and \\ BARBARA S. MARGARET
}

Department of Microbiology, University of Maryland School of Dentistry, Baltimore, MD 21201 and *Department of Oral Biology, University of Florida College of Dentistry, Gainesville, FL 32610, USA

\begin{abstract}
Summary. Eubacterium yurii subsp. yurii is an anaerobic, gram-positive rod. On isolation $E$. yurii forms cellular arrangements resembling test-tube brushes (TTB). Although TTB decreased in size and number on repeated laboratory subculture in enriched media, media poor in available iron enhanced formation of these. Plasmids were not demonstrated, even after chloramphenicol enhancement. To characterise the nature and possible physiological roles of the structures of the TTB, they were examined by transmission electronmicroscopy (TEM) with thin-section, negative-staining, shadow-casting, freeze-etching and freezefracturing techniques, and by scanning electronmicroscopy (SEM). Previous studies by phase-contrast microscopy revealed an amorphous core, the size of which varied in direct proportion to the number of associated bacterial cells. Thin sections of the TTB showed a gram-positive cell wall with additional surface layers. Negative staining, shadow casting and freeze etching revealed a surface layer comprising subunits in tetragonal array (P4 symmetry). Shadow casting showed also that the outermost layer of the cells was composed of fibrillar structures closely associated with, but distinct from, the tetragonal layer. The fibrils extended from the cell surface in clumps or strands. The presence of these fibrils was confirmed by the freeze-fracture technique and SEM. Chemical analysis of the core material of the TTB showed it to be low in carbohydrate $(0.06 \%)$ and protein $(0 \cdot 2 \%)$. Energydispersive X-ray spectrometry showed that the core was composed mostly of iron. SEM evidence suggests that the intertwining of the fibrils of several individual cells was responsible for the unique brush-like arrangements characteristic of $E$. yurii and may function to entrap or localise iron within the core, possibly as a mechanism of iron sequestration.
\end{abstract}

\section{Introduction}

In 1881 , various three-dimensional "brush-like" bacterial masses of gram-negative and gram-positive organisms were observed microscopically in specimens taken from the oral cavity. Most of these arrangements have been shown to occur as a result of co-aggregation; e.g., streptococci with Actinomyces spp., and Bacteroides spp. with Fusobacterium spp. ${ }^{1-3}$ These structures are formed as a result of direct cellto-cell contact and are stabilised by lectin bonds. ${ }^{4}$ However, Eubacterium yurii, an anaerobic grampositive rod isolated from the subgingival dental plaque of patients with chronic periodontitis, differed from co-aggregating and from other brush-forming bacteria in that it formed homotypic (monospecific) aggregates of cells embedded in an amorphous material that seemed to be synthesised by the cells during growth. ${ }^{5,6}$
These studies were undertaken to examine the formation of the test-tube brush (TTB) arrangements with special emphasis upon their structure, expression and possible function.

\section{Materials and methods}

\section{Microscopy}

E. yurii subsp. yurii strain CSF (ATCC 43713) was grown for $72 \mathrm{~h}$ in Schaedler Broth (SB; Difco) in anaerobic conditions in a Coy chamber in an atmosphere of $\mathrm{N}_{2} 85 \%, \mathrm{H}_{2} 10 \%, \mathrm{CO}_{2} 5 \%$ (Coy Laboratory Products, Ann Arbor, MI). Cells were examined by transmission electronmicroscopy (TEM) with a Zeiss 10A High Resolution Electron Microscope, and by scanning electronmicroscopy (SEM) with a Jeol JSM35C Scanning Electron Microscope.

Whole cells were harvested, washed in $0 \cdot 1 \mathrm{M}$ sodium cacodylate buffer $(\mathrm{CB})$, placed on carbon-stabilised

Received 16 Feb. 1991; accepted 25 Feb. 1991. 
formvar-coated grids, stained with uranyl acetate $1 \%$ or aqueous phosphotungstic acid $1 \%$, then viewed by TEM.

To prepare thin sections for TEM, cells were washed in $\mathrm{CB}$, fixed initially with glutaraldehyde $0.5 \%$ in $\mathrm{CB}$, post-fixed overnight with buffered osmium tetroxide $1 \%$, dehydrated through a graded ethanol series (30$100 \%$ ) and embedded in EPON 812 (E. Fullam, Inc., Latham, NY). Thin sections were stained with saturated aqueous uranyl acetate and aqueous lead citrate. $^{7}$

For shadow casting, cells were washed in $0.01 \mathrm{M}$ phosphate buffer in $0.15 \mathrm{M} \mathrm{NaCl}$ (PBS), placed on carbon-stabilised formvar-coated grids, fixed for 10 min with glutaraldehyde $3 \%$ in $\mathrm{CB}$, dried and coated with $1.65-2.0 \mathrm{~nm}$ of carbon-platinum before being examined by TEM.

For freeze fracturing and freeze etching, the cells were either treated with glycerol $30 \%$ in CB or left untreated, quick-frozen with liquid freon, cooled with liquid nitrogen and fractured, or fractured and then etched in a Balzer 301 freeze-fracture plant (Balzer, Hudson, NH) equipped with electron-beam guns. Deposition of $2 \mathrm{~nm}$ of platinum at an angle of $35^{\circ}$ was monitored by a quartz crystal monitor. Specimens were then coated with approximately $10-15 \mathrm{~nm}$ of carbon. Replica samples were digested with sodium hypochlorite $50 \%$, washed, dried and examined by TEM. $^{8}$

For SEM, cells were washed in CB, fixed for $1 \mathrm{~h}$ with glutaraldehyde $3 \%$ in $\mathrm{CB}$, dehydrated through a graded acetone series $(50-100 \%)$, critical point dried in $\mathrm{CO}_{2}$, mounted and sputter-coated with goldpalladium before being examined by SEM.

\section{Isolation of TTB core material}

A 48-h culture of $E$. yurii grown in SB was harvested, washed twice with $2 \mathrm{M} \mathrm{NaCl}$ and distilled $\mathrm{H}_{2} \mathrm{O}$, and resuspended in glucose $20 \% \mathrm{v} / \mathrm{v}$ in $50 \mu \mathrm{M}$ Tris, $\mathrm{pH} 7$. Cells were treated with mutanolysin $0.1 \mathrm{mg} / \mathrm{ml}$ for $60 \mathrm{~min}$ and then with Proteinase $\mathrm{K} 40 \mu \mathrm{g} / \mathrm{ml}$ for $60 \mathrm{~min}$. Cell lysis was completed by adding both sodium edetate, $\mathrm{pH} 8$, and sodium dodecyl sulphate (final concentration $0.5 \%$ ), followed by incubation on ice for $15 \mathrm{~min}$. The suspension was diluted $1: 3(\mathrm{v}: \mathrm{v})$ with KOAc, pH 4.8, incubated for $15 \mathrm{~min}$ and centrifuged at $31000 \mathrm{~g}$ for $30 \mathrm{~min}$ at $4^{\circ} \mathrm{C}$. The pellet containing core material was partially purified by

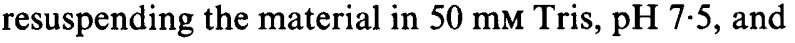
shearing it by passing the suspension through $22 \mathrm{G}$ and $25 \mathrm{G}$ needles. Core material and some attached ghost cells were recovered by filtration $(5 \mu \mathrm{m})$, suspended in $50 \mathrm{~mm}$ Tris buffer, $\mathrm{pH} 7 \cdot 5$, washed twice, resuspended in buffer, and frozen at $-20^{\circ} \mathrm{C}$ until further use.

\section{Protein and carbohydrate (CHO) determinations}

$\mathrm{CHO}$ and protein concentrations of the partially purified core material were determined by the Dubois method $^{9}$ and the BCA Protein Assay, ${ }^{10}$ respectively.

\section{$X$-ray spectrometry}

Core material was further purified by centrifugation in sucrose $70 \%$ (4000 $\mathrm{g}$ for $10 \mathrm{~min}$ ). The pellet was

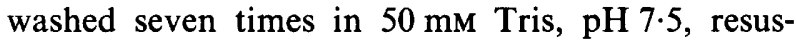
pended in buffer and examined by energy-dispersive $\mathrm{X}$-ray spectrometry (Kevex 7000) with a Jeol $100 \mathrm{CX}$ Electron Microscope). ${ }^{11}$

\section{Plasmid detection}

To amplify any plasmids present, cells of $E$. yurii were grown in a similar manner except that chloramphenicol $170 \mu \mathrm{g} / \mathrm{ml}$ was added after $48 \mathrm{~h}$ and the culture was incubated for a further $24 \mathrm{~h}$ before harvesting. After DNAase inactivation $\left(70^{\circ} \mathrm{C}\right.$, $30 \mathrm{~min}$ ), cells were lysed as described above. Lysates were examined for the presence of plasmids by agarosegel electrophoresis.

\section{Effects of iron concentration, iron source and iron chelator on TTB formation}

E. yurii was subcultured four times sequentially in various complex (C) and chemically defined (CD) media (table I) to study the effect of medium composition on TTB formation. Trypticase Soy Broth (Baltimore Biological Laboratory, Cockeysville, MD) was supplemented as indicated in table I. The various CD media were modifications of the basal medium of Terlecky et al. ${ }^{12}$ without glucose and sodium carbonate. All chemicals were obtained from Sigma Chemical Co., St. Louis, MO. In preparation of both C and CD media, double distilled water was used and all glassware was washed with RBS-35 (Pierce Chemical Co., Rockford, IL.) to avoid iron contamination. The incubation time for the CD media was increased by $48 \mathrm{~h}$ because of slower growth. Finally, unsupplemented SB was inoculated with $E$. yurii from the third subculture of the four $\mathrm{C}$ media. Cultures were examined microscopically to quantify TTB formation. A TTB was defined as at least five cells distally aggregated, with or without a visible core, and these were counted by phase contrast microscopy in ten $100 \times$ fields. Very large masses were counted as the number of individual TTB aggregates within the mass. Results were graded as follows: $1-4 \mathrm{TTB}=1+$; 5$10=2+; 11-17=3+; \geq 18=4+$. If no TTB were observed in ten fields, a further ten fields were examined.

\section{Results}

Examination of thin sections of individual $E$. yurii cells by TEM (fig. 1) revealed the presence of a grampositive cell wall with additional external layers. 
Table I. Formulations of chemically defined (CD)* and complex (C) media

\begin{tabular}{|c|c|c|c|c|c|c|c|c|c|c|}
\hline \multirow{2}{*}{ Components } & \multirow{2}{*}{$\begin{array}{l}\text { Concentration } \\
(\mu \mathrm{g} / \mathrm{ml})\end{array}$} & \multicolumn{4}{|c|}{ Chemically defined media } & \multicolumn{5}{|c|}{ Complex media } \\
\hline & & $\begin{array}{c}\mathrm{CD} \\
6 \mathrm{a}\end{array}$ & $\begin{array}{l}C D \\
6 b\end{array}$ & $\begin{array}{c}\mathrm{CD} \\
7\end{array}$ & $\begin{array}{c}\mathrm{CD} \\
8\end{array}$ & $\mathrm{C}$ & $\begin{array}{l}\mathrm{C} \\
1\end{array}$ & $\begin{array}{l}\mathrm{C} \\
2\end{array}$ & $\begin{array}{l}\mathrm{C} \\
4\end{array}$ & $\begin{array}{l}\mathrm{C} \\
5\end{array}$ \\
\hline Trypticase Soy & 30000 & $-*$ & - & ! & - & + & + & + & + & + \\
\hline $\mathrm{CaCl}_{2}$ & 20 & + & + & + & + & - & - & - & - & - \\
\hline Trizma & 3000 & + & + & + & + & + & + & + & + & + \\
\hline L-cysteine & 400 & + & + & + & + & + & + & + & + & + \\
\hline $\mathrm{K}_{2} \mathrm{HPO}_{4}$ & 24 & + & + & + & + & - & - & - & - & - \\
\hline $\mathrm{KH}_{2} \mathrm{PO}_{4}$ & 27 & + & + & + & + & - & - & - & - & - \\
\hline Pyridoxal-HCl & 4 & + & + & + & + & - & - & - & - & - \\
\hline Pyridoxine- $\mathrm{HCl}$ & 4 & + & + & + & + & - & - & - & - & - \\
\hline Tween 80 & $0.75(\% \mathrm{v} / \mathrm{v})$ & + & + & + & + & - & - & - & - & - \\
\hline Sodium pyruvate & 1000 & + & + & + & + & - & - & - & - & - \\
\hline \multirow[t]{2}{*}{ Haemin } & 1 & + & - & - & - & - & - & - & - & - \\
\hline & 10 & - & + & - & - & - & - & - & - & + \\
\hline Iron sulphate & $0 \cdot 2$ & - & - & + & + & + & + & + & + & - \\
\hline \multirow[t]{3}{*}{ 2'2'-dipyridyl } & $0 \cdot 1$ & - & - & - & - & - & + & - & - & - \\
\hline & $0 \cdot 2$ & - & - & - & - & - & - & + & - & - \\
\hline & $0 \cdot 4$ & - & - & - & + & - & - & - & + & - \\
\hline
\end{tabular}

All other ingredients of the basal medium of Terlecky et al. ${ }^{12}$ were added with the exception of glucose and sodium carbonate.

* + , Component present in medium; - , component not present in medium.

Shadow casting demonstrated a uniform, sheet-like surface layer composed of subunits in a tetragonal array (P-4 symmetry) (fig. 2). The presence of this surface layer was confirmed by negative staining and by freeze etching (fig. 3); multiple surface layers were also visible in the latter preparation.

Furthermore, shadow casting showed that the outermost cell layer was composed of long, thin fibrillar structures $(c .0 .035 \mu \mathrm{m}$ in diameter) that extended from the cell surface in bundles or strands, and differed morphologically from flagella and pili. The fibrils appeared to be closely associated with, yet distinct from, the tetragonal surface layer (fig. 2). The presence of the fibrillar structures was also demonstrated by the freeze-fracture technique (fig. 4) and by SEM (fig. 5). Furthermore, SEM showed that the fibrils were closely associated with the core region of

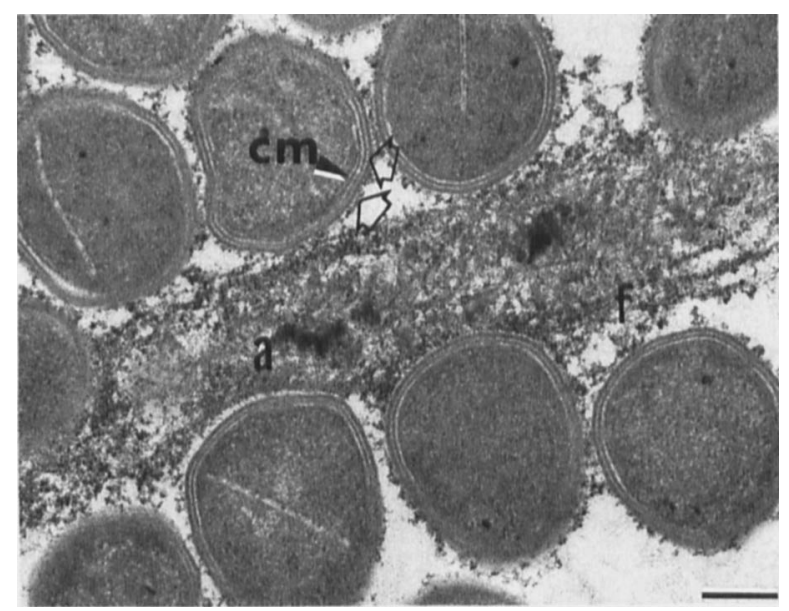

Fig. 1. Thin section through TTB form. Gram-positive wall structure and surface layers are apparent. The core is acellular: $(\mathrm{cm})$ cell membrane; arrows indicate surface layers; (a) amorphous core region; (f) fibrillar core region. $\mathrm{Bar}=\mathbf{0 . 2 \mu \mathrm { m }}$. the TTB aggregates, where they formed a tangled mass (fig. 5). In thin sections of TTB forms examined by TEM, the core region was not uniformly amorphous; distinctly fibrillar areas were apparent (fig. 1). SEM images also revealed the presence of crystalline material trapped within the intertwined fibrils of the core (fig. 5).

The examination of the sucrose-purified core material by energy dispersive X-ray spectrometry revealed the presence of trace amounts of silicon (probably from laboratory glassware) and large quantities of chloride and iron (fig. 6). The chloride could have come from the Tris-buffer in which the sample was resuspended. An interesting finding was the presence of iron which constituted the majority of the weight of the TTB core material.

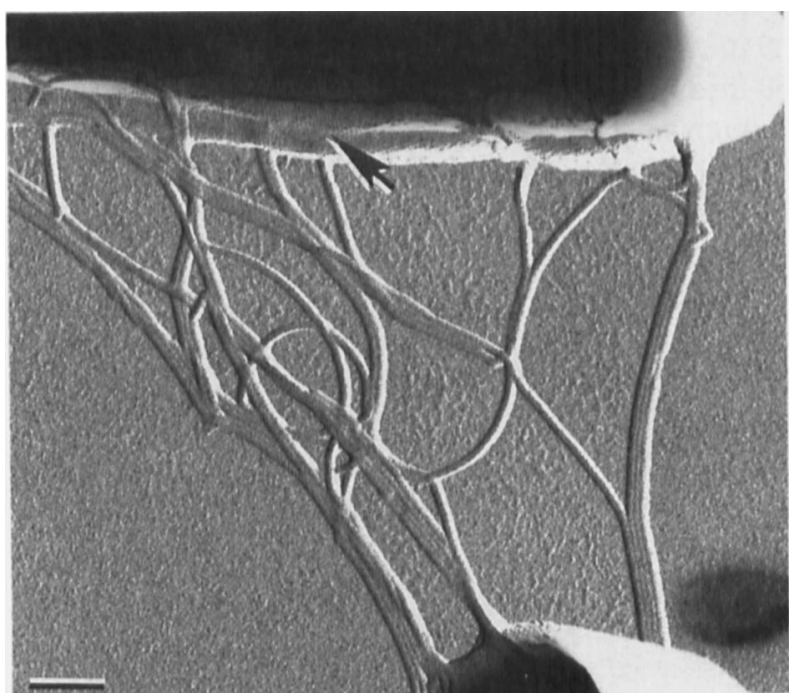

Fig. 2. Shadow casting of cells revealing the surface layer composed of subunits arranged in tetragonal array (arrow), and distinct fibrils extending away from the outermost cell surface. Bar $=0.2 \mu \mathrm{m}$. 


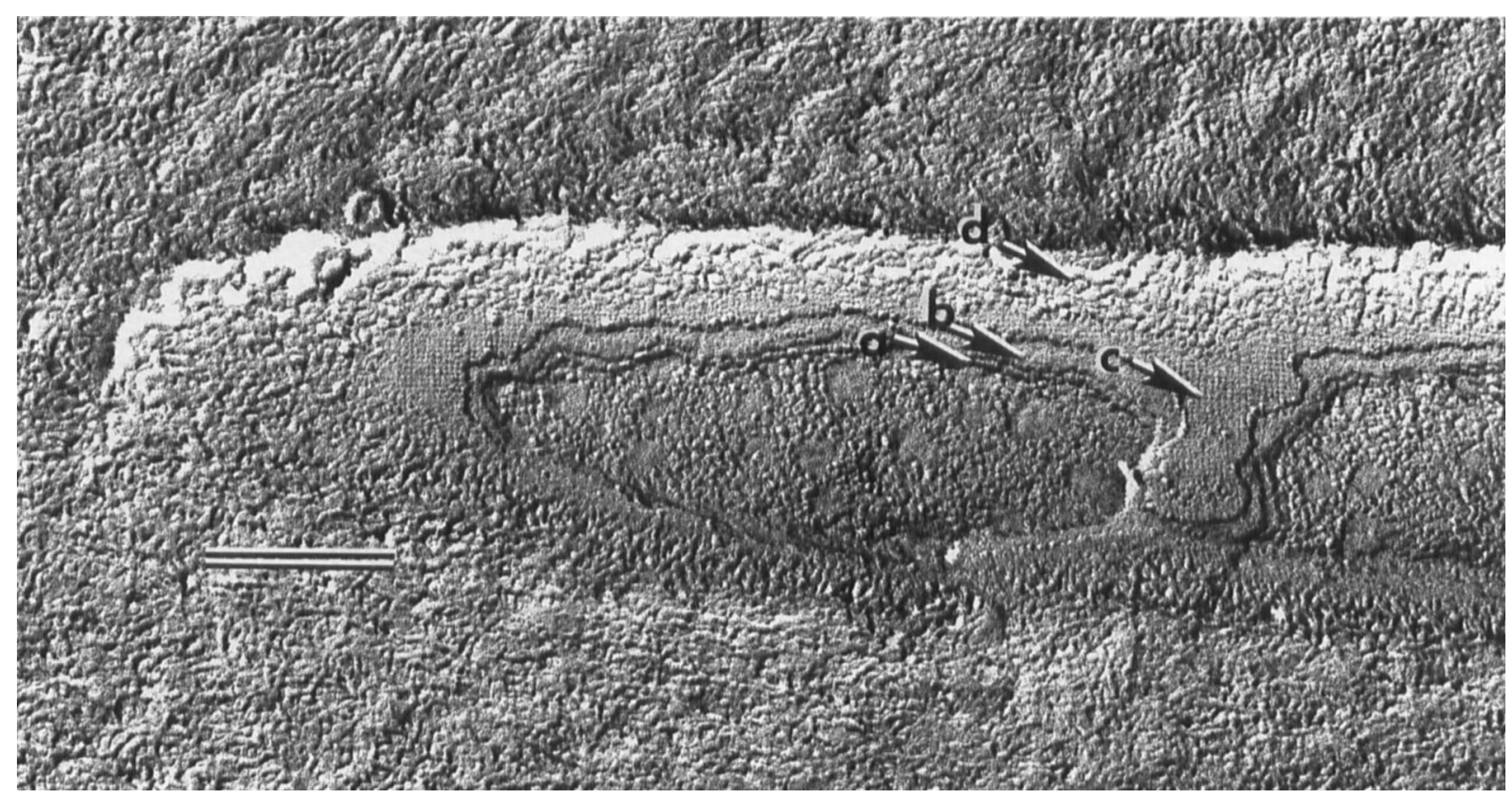

Fig. 3. Freeze etching of whole cell; several distinct layers are evident (arrows): (a) cell membrane; (b) peptidoglycan; (c) tetragonallyarranged (P4 symmetry) surface (S) layer; (d) outermost layer. Bar $=0.2 \mu \mathrm{m}$.

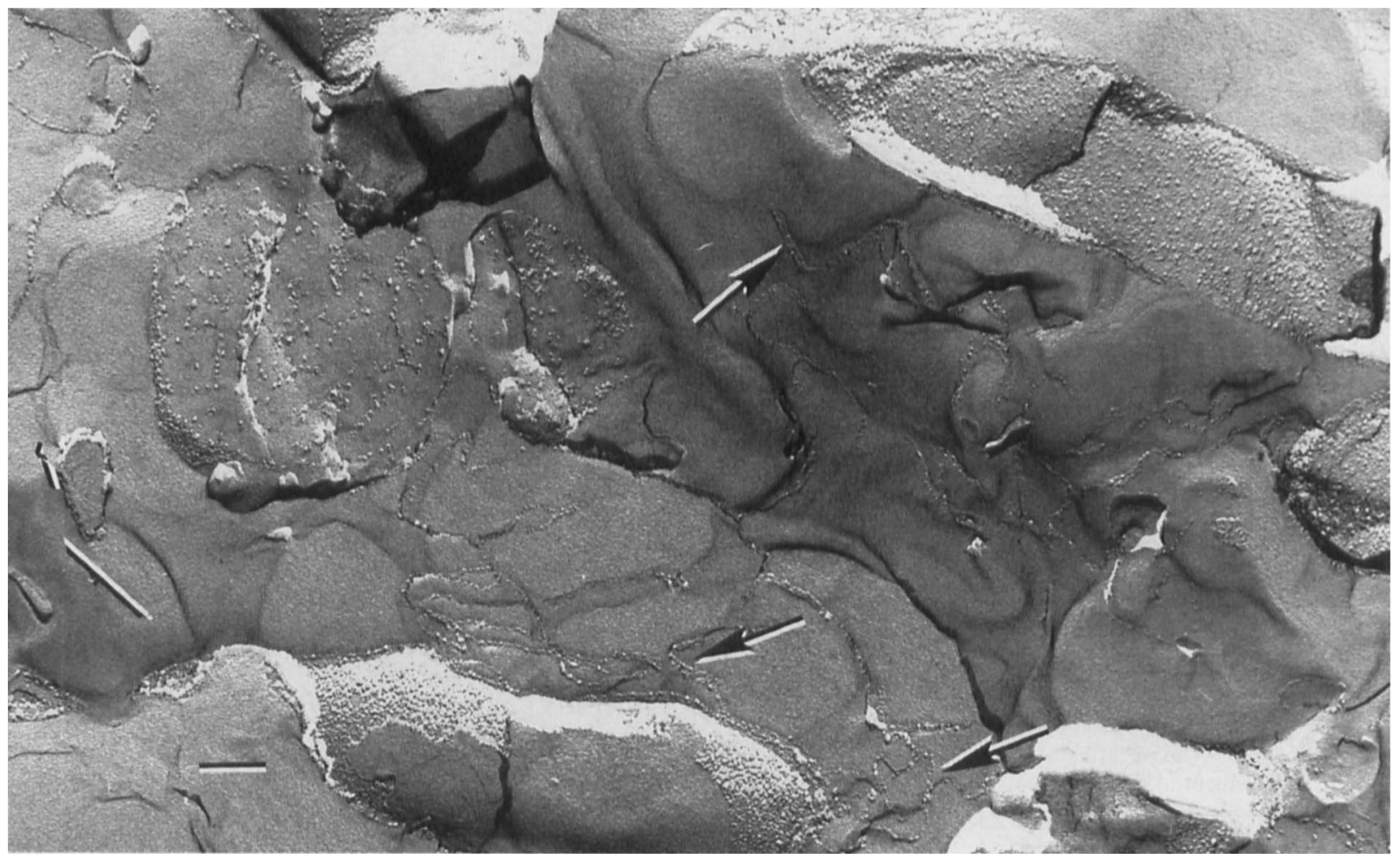

Fig. 4. Freeze fracturing of whole cell showing outermost fibrillar layer and fibrils peeling away from surface (arrows). Bar $=0 \cdot 2 \mu \mathrm{m}$.

No plasmids were detected by agarose gel electrophoresis of lysates from untreated or chloramphenicoltreated cells.

The Dubois ${ }^{9}$ carbohydrate determination was performed on the partially purified core material with glucose as a standard. The final concentration of carbohydrate was $0.06 \%$. The Pierce BCA protein assay ${ }^{10}$ of the partially purified core material, with albumin as a standard, indicated a final protein concentration of $0.2 \%$. However, since the cells were treated with Proteinase $\mathrm{K}$ in the isolation procedure, the amount of protein in the core material could be higher than reported here.

The effects of iron concentration, iron source and iron chelator on TTB formation are summarised in table II. In $\mathrm{C}$ medium with iron sulphate and no iron chelator, the number of TTB was constantly low, but on transfer into SB, there was a dramatic increase in the number of TTB. In $\mathrm{C}$ media containing an iron chelator, an increase in the number of TTB was 


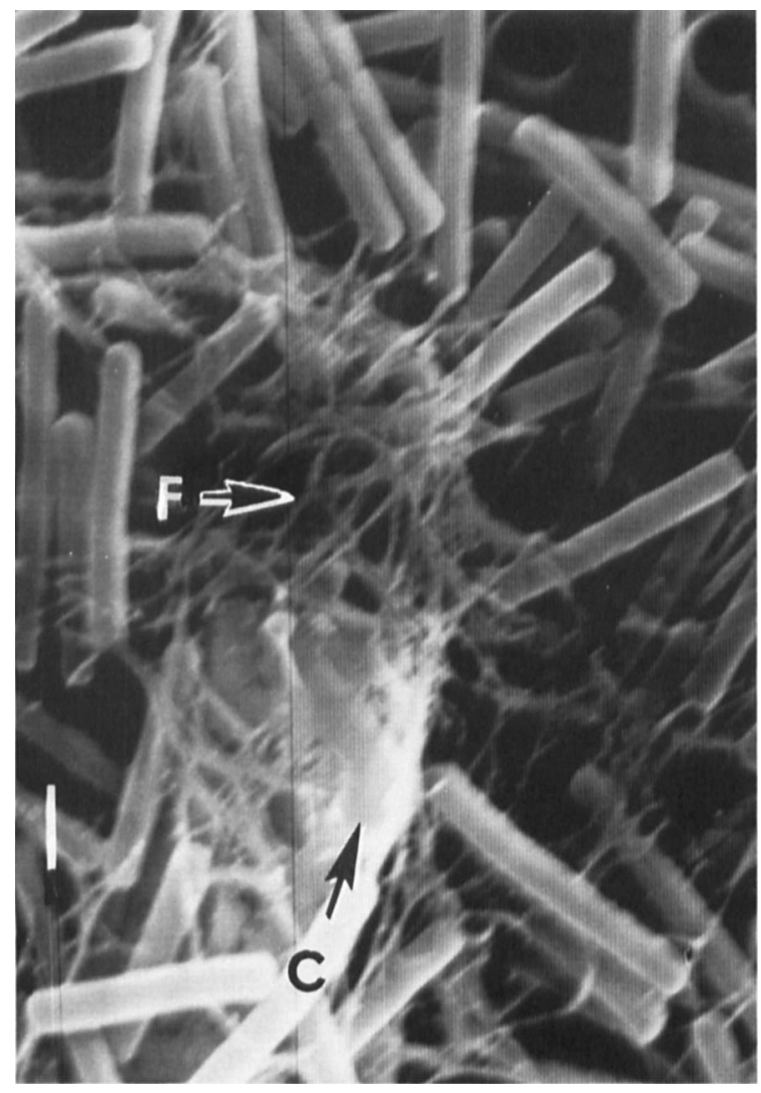

Fig. 5. SEM photomicrograph of TTB form that has been disrupted, revealing the core region. Fibrils are apparent $(F)$, and the crystalline material (C) appears to be associated with the core region and the fibrillar meshwork. Bar $=1.0 \mu \mathrm{m}$.

observed with successive transfers. On transfer from complex media into SB, and during subsequent subculture in $C D$ media, there was a decrease in the number of TTB observed.

The number of TTB remained relatively constant in CD6a, but in CD6b, the TTB were eliminated after two transfers. No TTB were seen after the first transfer into CD7. Finally, on the first transfer into CD8, if no TTB were present, growth was minimal and there was no growth on further subculture.

Table II. Microscopic counts of TTB in various media

\begin{tabular}{cccccc}
\hline & \multicolumn{3}{c}{$\begin{array}{c}\text { Count* after } \\
\text { Medium }\end{array}$} & \multicolumn{3}{c}{ sequential subculture no. } & $\begin{array}{c}\text { Count after } \\
\text { subculture into SB }\end{array}$ \\
\cline { 2 - 5 } & 1 & 2 & 3 & 4 & \\
\hline Complex & & & & & \\
C & $1+$ & 0 & $1+$ & $1+$ & \\
C1 & 0 & $1+$ & $2+$ & $4+$ & $1+$ \\
C2 & $1+$ & $2+$ & $1+$ & $2+$ & $1+$ \\
C4 & $1+$ & $1+$ & $4+$ & $4+$ & $1+$ \\
Chemically defined & & & & \\
CD6a & $2+$ & $1+$ & $1+$ & $1+$ & \\
CD6b & $2+$ & $2+$ & 0 & 0 & \\
CD7 & $3+$ & 0 & 0 & 0 & \\
CD8 & 0 & NG & NG & NG & \\
\end{tabular}

* $1+, 1-4 ; 2+, 5-10 ; 3+, 11-17 ; 4+,>18 ; \mathrm{NG}$, no growth; 0 , no TTBs were detected in 20 fields.

$\mathrm{SB}$, Schaedler Broth.

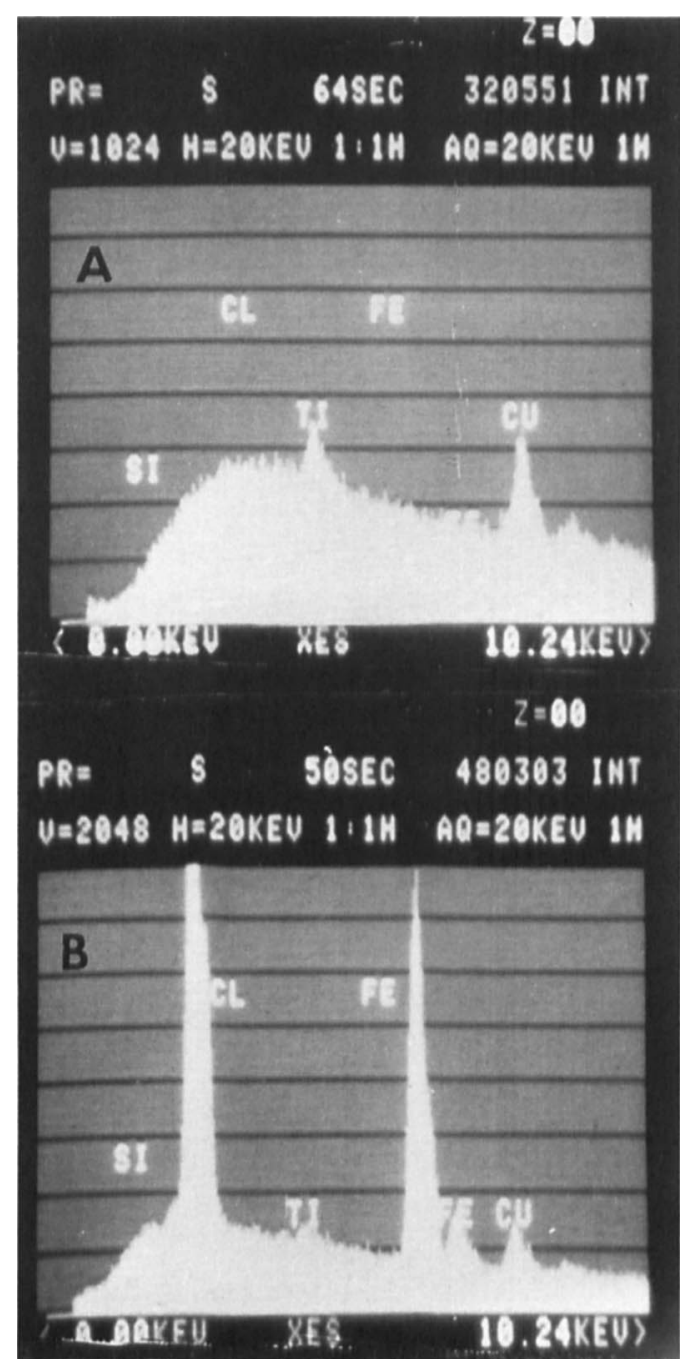

Fig. 6. Energy dispersive $\mathrm{X}$-ray spectrometric analysis of core material revealing that the majority is iron: (A) control; (B) core material.

\section{Discussion}

Several investigators have described intergeneric co-aggregation within the subgingival plaque. ${ }^{4}$ The TTB aggregates of $E$. yurii, however, are unique in two respects: firstly, the aggregates are monospecific rather than intergeneric (multispecific), and secondly, the cellular mass is stabilised by a core of amorphous material of cellular origin and not by direct cell-to-cell binding seen in true co-aggregation.

The occurrence of TTB in direct smears of subgingival plaque ${ }^{13}$ indicates that these forms naturally occur in vivo, but with prolonged laboratory subculture the tendency to aggregate disappears. Since this phenomenon was similar to plasmid curing, ${ }^{14}$ we tried initially to identify a plasmid, but failure to demonstrate this indicated that there must be another explanation.

The discovery that the core material consisted primarily of iron added a new facet to the investigation. Iron limitation is a host defence mechanism against infection, but many pathogens have the ability to acquire iron from the host, thus enhancing their 
virulence. ${ }^{15-17}$ The possibility that the core material either acts as an ion trap, or serves as a mechanism to sequester or store iron, indicates that this species may have a competitive advantage in a densely populated environment. The ability of $E$. yurii to sequester iron in aggregates could enhance its virulence.

Various bacteria have been shown to possess one or more paracrystalline surface (S) layers. ${ }^{18,19}$ Although their precise functions have yet to be fully elucidated, $S$ layers may play a role in surface recognition and cell adherence or may serve as ion or molecular traps. The $\mathrm{S}$ layer also may serve as a virulence factor. ${ }^{19}$

The tetragonally-arranged layer (P4 symmetry) described here appears to be morphologically similar to the $\mathrm{S}$ layer described by Kerosuo et al. ${ }^{20}$ in their electronmicroscope study of an anaerobic grampositive rod of the genus Eubacterium isolated from an infected root canal. However, the fibrils seen in association with TTB arrangements observed in the present study in $E$. yurii have not been described previously. From morphological evidence, they do not appear to be either flagella or pili; $E$. yurii has previously been shown to possess a single, subpolar flagellum. ${ }^{5}$

In SEM and thin sections, the outermost layer of individual cells extends away from the surface, giving the appearance of fibrils peeling away from the cell singly and in small bundles. Fibrils from several cells may become intertwined, forming a mesh-like structure that is the framework of the core region. This meshwork appears to bind cells together and, therefore, may be responsible for the unique brush-like arrangements of the cells. The intertwined fibrils could also trap or localise the crystalline material seen in the core by SEM.

Energy dispersive X-ray spectrometry studies of the crystalline material associated with the core region indicated that the crystals were composed mainly of iron with $<1 \%$ organic material.

These results tempt speculation about the relationship of the fibrillar layer, the formation of the brushlike aggregates and the presence of iron in the core region. Since the outer surface of bacterial $\mathrm{S}$ layers is usually negatively charged, ${ }^{19}$ it is possible that positively charged iron ions could bind to the fibrillar layer, causing it to pull away from the tetragonal layer beneath it. Brush formation could then occur either by the random, physical entangling of loose fibrils from many neighbouring cells, or by ionic bridging by the iron moiety between fibrils from different cells.

Our results seem to indicate that decreasing TTB formation in vitro is not due to plasmid curing, but appears to be related to the iron content of culture media. Poor formation of TTB under conditions of iron excess is readily reversible when the availability of iron is diminished.

In studying the production of TTB in a complex (C) medium containing iron and dipyridyl, it appeared that the TTB could be maintained by subculturing. TTB were not maintained in $\mathrm{C} 2$, possibly due to contaminating iron. Another result of note was the dramatic change in the numbers of TTB when cultures were transferred from various complex media into SB, formulated to contain about $10 \mu \mathrm{g}$ of haemin $/ \mathrm{ml}$, but which may have other iron sources. It could be speculated that when the iron source was altered, the requirement for the aggregation of TTB also changed. For example, in a complex medium, the iron supplied as $\mathrm{FeSO}_{4}$ was readily available for uptake into the cell and iron sequestration (TTB formation) was less urgent. On transfer into a haemin-containing medium, the cells may have recognised the medium as iron deficient and required the TTB mechanism to sequester the available iron. During subsequent growth in the presence of haemin (SB), the cells eventually stored enough iron so that the formation of TTB was no longer needed. Cells grown under iron-deficient conditions of $\mathrm{C} 1, \mathrm{C} 2$ and $\mathrm{C} 4$, with the iron sequestering TTB mechanism functional, adapted quickly when transferred into a haemin-containing medium. The change to a relative iron excess possibly eliminated the need for TTB formation.

Even though growth was minimal in the chemically defined media, the results seemed to substantiate the theory that $E$. yurii will form TTB when iron is not readily available. With small amounts of haemin (CD6a) the TTB were minimally maintained, but with increased quantities of haemin (CD6b), the TTB disappeared after two transfers. Finally, with readily available iron (CD7), the TTB were lost after one transfer. CD8 could not support the growth of $E$. yurii because the chelator bound almost all of the iron, thereby inhibiting growth.

The growth of E. yurii is influenced by iron. Since aggregates of TTB are seen in direct smears of subgingival plaque, ${ }^{13}$ it may be concluded that the iron available in the environment is limited. Within the periodontal pocket, high numbers ( $>10^{9}$ cells) of many species of bacteria compete for available nutrients, including iron. Binding of iron in high concentrations by a single group of organisms within a large, diverse mass of bacteria could be a means of iron sequestration that might confer a competitive advantage to these organisms within the pocket. Even when lysed red blood cells are present in the periodontal pocket, which occurs commonly at a diseased site, there is competition within the microbial population for iron. Some periodontal pathogens, e.g., Bacteroides spp., require haemin for growth, ${ }^{21}$ and many species have been shown to require iron for their growth.

The intertwined fibrils of $E$. yurii (fig. 2) may be a mechanism of iron sequestration for subsequent transport into the cell. Also, the tetragonal layer (figs. 2,3 ) of the cell may contain an iron receptor and the intertwining fibrils may be merely ion traps; moreover siderophores may exist which transport iron to fibrillar or tetragonal layer receptors. Finally, when iron becomes sufficient, aggregation of TTB may be "turned off" at the genetic level, whereas during iron 
deficiency, it is "turned on". Studies have shown that iron itself can act as a co-repressor in some species, to "turn off" transcription of iron-acquiring protein genes in conditions when the supply of iron is adequate. $^{22}$

Members of the genus Eubacterium are increasingly recognised as potential pathogens $s^{23-25}$ and since a relationship has been demonstrated between pathogenicity and iron acquisition, ${ }^{16,17}$ the pathogenic potential of $E$. yurii should be investigated in the periodontal pocket. Previous studies have shown that

\section{References}

1. Johne (1881) Cited in Davis DJ. The Actinomyces-like granules in tonsils. $J$ Infect Dis $1914 ; 14: 144-158$

2. Tunnicliff R, Johnson L. Vibriothrix tonsillaris n.sp., the organism of Actinomyces-like tonsillar granules. $J$ Infect Dis $1930 ; 46: 12-17$

3. Listgarten MA. Structure of the microbial flora associated with periodontal health and disease in man. J Periodontol 1976 ; 47: $1-18$

4. Kolenbrander PE. Intergeneric coaggregation among human oral bacteria and ecology of dental plaque. Annu Rev Microbiol 1988; 42: 627-656.

5. Margaret BS, Krywolap GN. Eubacterium yurii subsp. yurii sp. nov. and Eubacterium yurii subsp. margaretiae, subsp. nov. test tube brush bacteria from subgingival dental plaque. Int J Syst Bacteriol 1986; 36: 145-149.

6. Margaret BS, Krywolap GN. Eubacterium yurii subsp. schtitka subsp. nov.: test tube brush bacteria from subgingival dental plaque. Int J Syst Bacteriol 1988; 38: 207-208.

7. Reynolds ES. The use of lead citrate at high $\mathrm{pH}$ as an electronopaque stain in electron microscopy. J Cell Biol $1963 ; 17$. 208-212.

8. Hudson CS, Rash IE, Graham WF. Introduction to sample preparation for freeze fracture. In: Rash JE, Hudson CS (eds) Freeze fracture: methods, artifacts and interpretations. New York, Raven Press. 1979: 1-10.

9. Dubois M, Gilles KA, Hamilton JK, Rebers PA, Smith F. Colorimetric method for determination of sugars and related substances. Anal Chem 1956; $28: 350-356$.

10. Smith PK, Krohn RI, Hermanson GT et al. Measurement of protein using bicinchoninic acid. Anal Biochem 1985; 150: 76-85.

11. Horner JA. Scanning transmission energy analyzing microscopy. In: Hayat MA (ed) Principle and techniques of scanning electron microscopy. Biological applications, vol. 6, New York, Van Nostrand Reinhold Co. 1978; 1-46.

12. Terleckyj B, Willet NP, Shockman GD. Growth of several cariogenic strains of oral streptococci in a chemically defined medium. Infect Immun 1975; 11; 649-655.

13. Margaret BS. Characterization of Eubacterium yurii sp. nov.: a test tube brush bacterium from subgingival dental plaque. extracts of whole cells of two subspecies of E. yurii stimulated bone resorption in vitro in much the same way as that induced by recognised periodontal pathogens. ${ }^{26}$

We thank Dr A. S. Bleiweis, Chairman of the Department of Oral Biology, University of Florida College of Dentistry, for providing the resources for G.N.K. to carry out part of this research during sabbatical leave; Evelyn Clausnitzer and Judy Pennington for technical assistance; and Drs Ann Progulske, W. A. Falkler and B. D. Tall for stimulating discussions.

Baltimore, MD, University of Maryland, (Dissertation) $1987 ; 1-146$.

14. Friefelder D. Microbial genetics. Boston, Jones and Bartlett Publishers. 1987; 268-269.

15. Archibald FS, DeVoe IW. Removal of iron from human transferrin by Neisseria meningitidis. FEMS $1979 ; 6$ : 159162.

16. Carniel E, AntoineJ-C, Guiyoule A, Guiso N, Mollaret HH Purification, location, and immunological characterization of the iron-regulated high-molecular-weight-proteins of the highly pathogenic Yersiniae. Infect Immun 1989; 57: 540545.

17. Lee BC, Bryan LE. Identification and comparative analysis of the lactoferrin and transferrin receptors among clinical isolates of gonococci. J Med Microbiol 1989; 28 : 199-204.

18. Koval SF. Paracrystalline protein surface arrays on bacteria Can J Microbiol 1988; 34: 407-414.

19. Sleytr UB, Messner P. Crystalline surface layers in procaryotes. $J$ Bacteriol 1988; 170: 2891-2897.

20. Kerosuo E, Haapasalo M, Lounatmaa K, Ranta H, Ranta K. Ultrastructure of a novel anaerobic gram-positive nonsporing rod from dental root canal. Scand J Dent Res 1988;96; 50-55.

21. van Winkelhoff AJ. Black-pigmented Bacteroides in human oral disease. Amsterdam, Free University Press. 1986; 6790.

22. Boyd RF. General microbiology. St Louis, Mosby College Publishing Co. $1988 ; 362$.

23. Hill GB, Ayers OM, Kohan AP. Characteristics and sites of infection of Eubacterium nodatum, Eubacterium timidum Eubacterium brachy, and other asaccharolytic eubacteria. $J$ Clin Microbiol 1987; 25 : 1540-1545.

24. Walker RL, MacLachlan NJ. Isolation of Eubacterium suis from cows with cystitis. J Am Vet Med Assoc 1989; 195: 11041107

25. Severijnen AJ, van Kleef R, Hazenberg MP, Van de Merwe JP. Chronic arthritis induced in rats by cell wall fragments of Eubacterium species from human intestinal flora. Infect Immun 1990; 58: 523-528.

26. Margaret BS, Heath JR, Krywolap GN. Pathogenic potential of Eubacterium yurii subspecies. J Med Microbiol 1990; 31 103-108. 